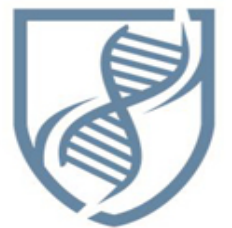

Journal of Bioscience and Applied Research
JBAAR

WWW.JBAAR.ORG

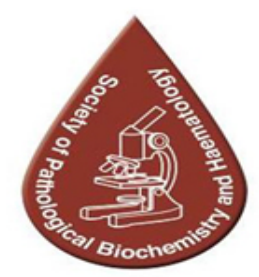

\title{
Effects of L-carnitine and Ginkgo biloba on Pentylentetrazol-induced liver damage and oxidative stress in rats
}

\author{
Reda M. Fekry ${ }^{1}$; Akaber TH Keshta ${ }^{1}$; Wafaa K.Abo-Ghaneima ${ }^{1}$; Ehab Tousson ${ }^{2 *}$ \\ ${ }^{1}$ Chemistry Department, Faculty of Science, Zagazig University, Egypt \\ ${ }^{2}$ Zoology Department, Faculty of Science, Tanta University, Egypt \\ (Corresponding author e.mail.toussonehab@yahoo.com)
}

\begin{abstract}
Pentylentetrazol (PTZ) kindling is an acknowledged models for epilepsy. The current study aimed to determine the possible protective and ameliorative effects of Lcarnitine and Ginkgo biloba (GB) against PTZ induced liver injury and oxidative stress in male rats. A total of 80 male albino rats were equally divided into eight groups; 1 st group was the control; 2nd and 3rd were GB and Lcarnitine groups, respectively; 4th group was pentylenetetrazole rat group and the 5th and 6th groups were pre and post treated PTZ with L-carnitine groups respectively; the 7th and 8th groups were pre and post treated PTZ with GB respectively. Serum ALT, AST, ALP and MDA in liver tissue were significant increase in PTZ group when compare with control, while serum ALB and CAT, SOD, GST and TAC in liver tissue were significant decrease in PTZ group when compare with control. On other hand post and pre-treatment with L-carnitine and GB improved these parameters. Our results revealed that the treatment with L-carnitine improved these parameters more than GB and the results of post treatment were better than pre-treatment
\end{abstract}

Keywords: Pentylentetrazol; L-carnitine; Ginkgo biloba; Liver functions; Oxidative stress

\section{Introduction}

Epilepsy is the neurological disorder of the human brain characterized by seizures affecting people of all ages, race, social class or geographical boundaries (Hermann et al., 2012). A seizure is an event and epilepsy is the disease involving recurrent un provoked seizures (Fisher et al., 2014). Pentylentetrazol (PTZ) kindling model provides a useful model for post seizure dysfunction, serving as a screen for potential treatments for the cognitive and emotional deficits that are observed in human epilepsy (Barbalho et al., 2016; Nasir et al., 2012). PTZis drug used as a $\mathrm{\gamma}$-aminobutyric acid (GABA) receptor antagonist with high biological membrane penetrance and consequent rapid bioavailability and distribution to all organs including the brain, and very short latency of seizure induction (Spencer et al., 2009).

The Ginkgo biloba tree is the oldest tree on earth that appeared in the Jurassic period 170 million years ago and for this reason, is called the "living fossil" (Nuhu, 2014; Tousson et al., 2014).Ginkgo biloba have also antioxidant properties, which are mainly connected to their polyphenolic constituents, particularly phenolic acids, flavonoids, proanthocyanidins and catechins (Koczka et al., 2015).

L-carnitineis a vitamin-like dietary compound that is synthesized in the body from and is important in mammalian metabolism, especially for the normal mitochondrial oxidation of fatty acids (Pochini et al., 2013; Ozsoy et al., 2011) Cellular energy metabolism is largely sustained by mitochondrial $\beta$-oxidation of fatty acids, especially when carbohydrate stores are depleted after fasting or prolonged exercise. The present study was aimed to investigate the role of Ginkgo biloba (GB) and Lcarnitine on the biochemical and oxidative stress alterations in Pentylentetrazol (PTZ) induced liver toxicity in male albino rat.

\section{Materials and Methods}

\section{a.Chemicals:}

The reagents Pentylenetetrazol (PTZ), thiobarbituric acid, 2,4dinitrophenylhydrazine, 5,5'-dithiobis(2- 
nitrobenzoic acid), (-)-epinephrine, chlorogenic acid and guanidine hydrochloride were purchased from SigmaAldrich (St. Louis, MO, USA).

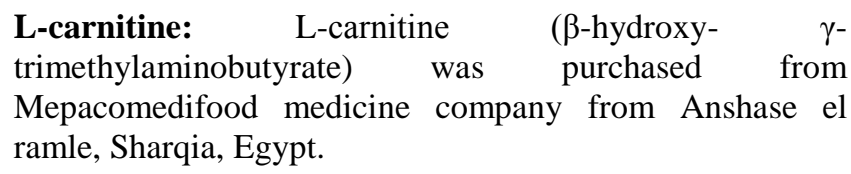

Ginkgo biloba: The plant Ginkgo biloba is dietary supplement for improving circulation and memory. The extract was purchased from (EMA Pharma pharmaceutical, Nozha, Nasrcity, Cairo, Egypt).

\section{b.Experimental animals}

The experimental protocol was approved by Local Ethics Committee and Animals Research. The experiments were performed using80 male albino rats (Rattusnorvigicus) weighing $120 \pm 10 \mathrm{~g}$ and of 7-8 weeks age. The rats were kept in the laboratory for one week before the experimental work and maintained on a standard diet and water was available ad libitum. The rats were equally divided into eight groups. $1^{\text {st }}$ group was control group in which rats never received any treatment. $2^{\text {nd }}$ group was given L-carnitine (300 mg/kg body weight)) once per day every other day for 9 days according to Tousson et al. (2014). $3^{\text {rd }}$ group was given GB $(100 \mathrm{mg} / \mathrm{kg}$ body weight))once per day every other day for 9 days according to Rodriguez de Turco et al. (1993). $4^{\text {th }}$ group was the experimental group that treated with pentylenetetrazol (PTZ; $40 \mathrm{mg} / \mathrm{kg}$ body weight) once per day every other day for 9 days according to Akula et al. (2007). $5^{\text {th }}$ group that injected with PTZ $(40 \mathrm{mg} / \mathrm{kg})$ once every $48 \mathrm{~h}$ for 9 days then treated with L-carnitine $(300 \mathrm{mg} / \mathrm{kg})$ once every $48 \mathrm{~h}$ for 9 days. $6^{\text {th }}$ group that treated with PTZ ( $40 \mathrm{mg} / \mathrm{kg}$ ) once every $48 \mathrm{~h}$ for 9 days after L-carnitine $(300 \mathrm{mg} / \mathrm{kg})$ treated once every $48 \mathrm{~h}$ for 9 days. $7^{\text {th }}$ group that treated with PTZ $(40 \mathrm{mg} / \mathrm{kg})$ once every $48 \mathrm{~h}$ for 9 days after $\mathrm{GB}(100$ $\mathrm{mg} / \mathrm{kg}$ ) treated once every $48 \mathrm{~h}$ for 9 days. 8th group that injected with PTZ $(40 \mathrm{mg} / \mathrm{kg}$ ) once every $48 \mathrm{~h}$ for 9 days then treated with GB $(100 \mathrm{mg} / \mathrm{kg})$ once every $48 \mathrm{~h}$ for 9 days.

\section{c. Biochemical analysis}

Tissue Homogenate

Prior to dissection, perfuse tissue with a PBS (phosphate buffered saline) solution, $\mathrm{pH}$ 7.4. Containing $0.16 \mathrm{mg} / \mathrm{ml}$ heparin to remove anyred blood cells and clots. The tissue was then homogenized in $5-10 \mathrm{ml}$ cold buffer (50 mM potassium phosphate, $\mathrm{pH}$ 7.4. $1 \mathrm{mM}$ EDTA) per gram tissue ,centrifuge at 4,000 rpm for 15 minutes at 4 ${ }^{\circ} \mathrm{C}$ a, remove the supernatant for assay and store on ice. The samples were then freeze at $-80^{\circ} \mathrm{C}$.

\section{Enzymatic and non-enzymatic antioxidant assays} Malondialdehyde (MDA) assay was detected by TBARS analysis and measured as reported by Ohkawa et al. (1979). Catalase (CAT) activity was detected according to the methods of Aebi (1984).Superoxide dismutase (SOD) was detected according to the methods of Nishikimi (1972). Glutathione-S- transferase (GST) was determined according to the method of Beutleret al. (1963).Total antioxidant capacity (TAC) activity was determined according to the method of Koracevic et al.(2001). Serum alanine aminotransferase (ALT) and aspartate aminotransferase (AST) were determined according to the method of Reitman and Frankel (1957). Serum Albumin concentration was determined according to the method of Bowers and Wong (1980). Serum alkaline phosphatase activitywas determined according to the method of Belfield and Goldberge (1971).

\section{Statistical Analysis:}

Data were expressed as mean values \pm SEM and statistical analyses were performed using SPSS statistical version 16 software package (SPSS ${ }^{\circledR}$ Inc., USA). The criterion for statistical significance was set at $\mathrm{p}<0.05$.

\section{Results}

Table (1) shows that SOD, CAT, GST and TAC levels in PTZ group showed significant decrease when compared with control, L-carnitine and GB groups. On the other hand, MDA levels in PTZ group showed significant increase when compared with control, L-carnitine and GB groups. In contrast, MDA levels in pre-treated PTZ group with L-carnitine or with GB groups (as in G5\&G7) were significantly decreased when compared with PTZ group while catalase, SOD, GST and TAC levels in pre-treated PTZ group with L-carnitine or with GB groups (as in G5\&G7) were significantly increased when compared with PTZ group. MDA levels in post treated PTZ group with Lcarnitineor with GB groups (as in G6\&G8) were significantly decreased when compared with PTZ group while catalase, SOD, GSH and TAC levels in post treated PTZ with L-carnitine or with GB groups (as in G6\&G8) were significantly increased when compared with PTZ group (Table 1). Table (2) shows that; a significant decrease in ALB levels in PTZ group while,serum ALT, AST and ALP levels in PTZ group were significantly increased when compared with control, L-carnitine and GB groups. In contrast, serum ALB levels were significantly increased in pre-treated PTZ group with L-carnitine or with GB groups (as in G5\&G7) when compared with PTZ group while serum ALT, AST and ALP levels in pre-treated PTZ group with L-carnitine or with GB groups (as in G5\&G7) were significantly decreased when compared with PTZ group (Table 2). Serum ALB levels was significant increase in post treated PTZ group with L-carnitine or with GB groups (as in G6\&G8) when compared with PTZ group while ALT, AST and ALP levels in post treated PTZ group with L-carnitine or with GB groups (as in G6\&G8) were significantly decreased when compared with PTZ group (Table2). 
Table 1: Changes in antioxidant and oxidative stress in different groups.

\begin{tabular}{|c|c|c|c|c|c|}
\hline Groups & $\begin{array}{c}\text { MDA } \\
(\mathbf{n} \text { mole/gm tissue })\end{array}$ & $\begin{array}{c}\text { CAT } \\
(\mathbf{U} / \mathbf{g})\end{array}$ & $\begin{array}{c}\text { SOD } \\
(\mathbf{U} / \mathbf{g m})\end{array}$ & $\begin{array}{c}\text { GSH } \\
(\mathbf{U} / \mathbf{g m})\end{array}$ & $\begin{array}{c}\text { TAC } \\
(\mathbf{m} \text { Mole/L) }\end{array}$ \\
\hline G1 & $10.77 \pm 0.47^{\mathrm{b}}$ & $1.78 \pm 0.030^{\mathrm{b}}$ & $1090 \pm 24.22^{\mathrm{b}}$ & $2.50 \pm 0.09^{\mathrm{b}}$ & $0.71 \pm 0.06^{\mathrm{b}}$ \\
\hline G2 & $12.00 \pm 0.57^{\mathrm{b}}$ & $2.48 \pm 0.030^{\mathrm{b}}$ & $1028 \pm 34.7^{\mathrm{b}}$ & $3.56 \pm 0.09^{\mathrm{b}}$ & $0.58 \pm 0.06^{\mathrm{b}}$ \\
\hline G3 & $12.17 \pm 0.70^{\mathrm{b}}$ & $2.20 \pm 0.036^{\mathrm{b}}$ & $943.3 \pm 25.7^{\mathrm{b}}$ & $4.18 \pm 0.16^{\mathrm{b}}$ & $0.61 \pm 0.04^{\mathrm{b}}$ \\
\hline G4 & $25.83 \pm 0.87^{\mathrm{a}}$ & $0.96 \pm 0.004^{\mathrm{a}}$ & $593.2 \pm 20.51^{\mathrm{a}}$ & $1.63 \pm 0.18^{\mathrm{a}}$ & $0.08 \pm 0.006^{\mathrm{a}}$ \\
\hline G5 & $17.0 \pm 0.73^{\mathrm{ab}}$ & $1.35 \pm 0.042^{\mathrm{ab}}$ & $783.3 \pm 22.31^{\mathrm{ab}}$ & $2.90 \pm 0.09^{\mathrm{ab}}$ & $0.33 \pm 0.04^{\mathrm{ab}}$ \\
\hline G6 & $11.50 \pm 0.34^{\mathrm{ab}}$ & $2.32 \pm 0.054^{\mathrm{ab}}$ & $949.8 \pm 30.4^{\mathrm{ab}}$ & $3.93 \pm 0.19^{\mathrm{ab}}$ & $0.55 \pm 0.04^{\mathrm{ab}}$ \\
\hline G7 & $13.00 \pm 0.96^{\mathrm{ab}}$ & $1.31 \pm 0.060^{\mathrm{ab}}$ & $758.2 \pm 19.61^{\mathrm{ab}}$ & $2.88 \pm 0.06^{\mathrm{ab}}$ & $0.50 \pm 0.07^{\mathrm{ab}}$ \\
\hline G8 & $13.00 \pm 0.51^{\mathrm{ab}}$ & $1.35 \pm 0.004^{\mathrm{ab}}$ & $923.2 \pm 28.6^{\mathrm{ab}}$ & $3.23 \pm 0.13^{\mathrm{ab}}$ & $0.165 \pm 0.007^{\mathrm{ab}}$ \\
\hline
\end{tabular}

Data are expressed as mean \pm S.E.M of 10 observations. $\left({ }^{\mathrm{a}}\right)$ significant difference compared to control group. $\left({ }^{\mathrm{b}}\right)$ highly significant difference compared to PTZ group, where G1, control group; G2, L-carnitine group; G3, GBgroup; G4, PTZ group; G5\&G6, pre- and post- treated PTZ with L-carnitine groups respectively; G7\&G8,pre- and post- treated PTZ withGinkgo bilobarespectively.

Table 2: Changes in liver functions in different groups

\begin{tabular}{|c|c|c|c|c|}
\hline Groups & ALT (U/L) & AST(U/L) & ALB (g/dl) & ALP(U/L) \\
\hline G1 & $35.70 \pm 0.66^{\mathrm{b}}$ & $190 \pm 8.60^{\mathrm{b}}$ & $3.41 \pm 0.08^{\mathrm{b}}$ & $373.3 \pm 19.54^{\mathrm{b}}$ \\
\hline G2 & $41.00 \pm 0.7^{\mathrm{b}}$ & $224 \pm 9.2^{\mathrm{b}}$ & $2.98 \pm 0.12^{\mathrm{b}}$ & $431.7 \pm 14.9^{\mathrm{b}}$ \\
\hline G3 & $40.80 \pm 0.7^{\mathrm{b}}$ & $224 \pm 9.2^{\mathrm{b}}$ & $3.25 \pm 0.07^{\mathrm{b}}$ & $433.3 \pm 13.33^{\mathrm{b}}$ \\
\hline G4 & $77.2 \pm 3.09^{\mathrm{a}}$ & $329 \pm 20.76^{\mathrm{a}}$ & $2.48 \pm 0.09^{\mathrm{a}}$ & $651.7 \pm 18.8^{\mathrm{a}}$ \\
\hline G5 & $44.28 \pm 1.54^{\mathrm{b}}$ & $274 \pm 15.88^{\mathrm{ab}}$ & $2.83 \pm 0.10^{\mathrm{ab}}$ & $496.5 \pm 9.50^{\mathrm{ab}}$ \\
\hline G6 & $41.20 \pm 0.86^{\mathrm{b}}$ & $278 \pm 11.58^{\mathrm{ab}}$ & $3.21 \pm 0.07^{\mathrm{b}}$ & $445.0 \pm 9.27^{\mathrm{ab}}$ \\
\hline G7 & $43.8 \pm 1.32^{\mathrm{b}}$ & $243 \pm 16.74^{\mathrm{ab}}$ & $3.00 \pm 0.07^{\mathrm{b}}$ & $493.3 \pm 10.22^{\mathrm{ab}}$ \\
\hline G8 & $43.8 \pm 1.24^{\mathrm{b}}$ & $280 \pm 15.81^{\mathrm{a}}$ & $2.71 \pm 0.07^{\mathrm{b}}$ & $475 \pm 17.63^{\mathrm{ab}}$ \\
\hline
\end{tabular}

Data are expressed as mean \pm S.E.M of 10 observations. ( $\left.{ }^{a}\right)$ Significant difference compared to control group. $\left({ }^{b}\right)$ highly significant difference compared to PTZ group, where G1, control group; G2, L-carnitine group; G3, GB group; G4, PTZ group; G5\&G6, pre- and post- treated PTZ with L-carnitine groups respectively; G7\&G8, pre- and post- treated PTZ with Ginkgo biloba respectively.

\section{Discussion}

Recurrent and prolonged seizures and anticonvulsant drugs may increase the concentration of ROS in the body, which may result in substantial deleterious effects on an individual's health. The liver is an organ that is sensitive to oxidative damage (Akbas et al., 2005). Seizures may lead to lipid peroxidation and decreased antioxidant defense mechanisms in hepatocytes (Dillioglugi et al., 2010). These types of damage may lead to epilepsy complications, such as fulminant liver failure (Akbas et al., 2005). Furthermore, anticonvulsant drugs may elevate liver enzyme levels, to deplete hepatic enzymatic antioxidant defenses, which may result in hepatotoxic effects or liver injury (Ochoa and Riche ,2012). Epileptic patients also present alterations in the redox status of their serum samples (Costello and Delanty 2004). Pentylenetetrazole-induced seizure activity mimics the increased oxidative stress in the brain by altering membrane phospholipid metabolism and ultimately resulting in the release of free radicals (Corvino et al., 2013). This work aimed to study the role of Ginkgo biloba $(\mathrm{GB})$ and L-Carnitine on the biochemical and oxidative stress alterations in Pentylentetrazol (PTZ) induced liver toxicity in male albino rat.

The current results indicated that pentylenetetrazole causes oxidative tissue damage by increasing lipid peroxidation and decreasing the level of antioxidant enzymes in the liver tissues. Our results agree with Akbas et al. (2005); Abdullah et al. (2008) and Dillioglugil et al. (2010) who reported that an increased in the levels of MDA in liver tissues in a mouse-seizure model after PTZ administration.

A significant reduction in MDA levels was observed in rat liver when treated with L-carnitine. This reduction is possibly due to the modulatory activity of L-carnitine in the antioxidant enzymes in the liver of adult rats. This indicates that L-carnitine inhibits liver damage as free radical scavenger. Similarly, Also; Tousson et al. (2015) find that; L-carnitine administration has decreased levels of MDA in brain tissues in rat seizure model. SOD and catalase are the main enzymes of the enzymatic antioxidant defense system, responsible for protection against the increase in ROS production (Nazıroglu et al., 2007). Catalase serves as an antioxidant defense mechanism and is primarily responsible for the removal of $\mathrm{H}_{2} \mathrm{O}_{2}$ from cells form of oxygen and a normal cellular metabolite. GST is one of the endogenous detoxifying antioxidant enzymes that lead to the formation of oxidized glutathione conjugates. Reduced GSH participates in the detoxification of xenobiotics as a substrate for the enzyme GST. Glutathione and other thiol containing proteins play a crucial key role in cellular defense against toxicity (Halliwell and Gutteridge 1999). 
In the present study; a significant decreasein SOD, catalase, GST and TAC levels were observed after PTZ administration.Previous study was reported, PTZ induced seizure shows marked reduction of antioxidant enzymes like glutathione reductase (Nieoczym et al., 2008). Also our results agree with Noaishi et al. (2013) who reported that decrease in catalase and GST due to oxidative stress in white rat.evaluation of tissue/organ total antioxidant capacity is valuable since it provides a gross estimation of how the body can react against oxidative and nitrosative injuries Constantini and Verhulst (2009).

In the assessment of liver injury the analysis of enzyme levels such as ALT and AST are largely used and located in the cytosol of hepatocytes. Necrosis or membrane damage releases the enzyme into the circulation and hence it can be measured in the serum. Clinical diagnosis of disease and damage to the structural integrity of liver is commonly assessed by monitoring the status of serum ALT and AST activities. The present study demonstrated significant decrease in ALB and significant increasein ALT, AST, and ALP levels were observed after PTZ administration. These results are accepted with those of Thapa and Walia (2007) who showed marked reduction in enzyme (ALT, AST and ALP) in the PTZ-induced kindled group which leads to the production of free radicals and existence of oxidative stress in the brain of the kindled mice. The present study demonstrating a significant increase in ALB while significant decrease in ALT, AST and ALP levels were observed in pre and post treatment with GB. These results are in accepted by Sato et al. (2009) who showed that GB can also enhance activities of enzymes, (ALT, AST and ALP), but not accepted with ALB which show no significant changes. This indicates the antioxidant action of GB. The present study also demonstrated that a significant increase in ALB while significant decrease in ALT, AST and ALP levels were observed in pre and post treatment with L-carnitine. These results are in accordance with the results of Canbaz et al. (2007) who showed that L-carnitine enhances activities of ALT, AST and ALP.

\section{References}

Abdullah A, Süleyman K, Mustafa Y, Nigar Y, Metin B, Hüseyin V, Sedat S, Mustafa N (2008). Nordic Pharmacological Society. Basic\& Clinical Pharmacology \& Toxicology ,103: 166-170.

Aebi H (1984). Catalase. In: Bergmeyer HU, (ed.) Methods of Enzymatic Analysis. New York: Academic Press pp. 673-84.

Akbas M, Akbas H, Yegin A, Sahin N, Titiz TA (2005). Comparison of the effects of clonidine and ketamine added to ropivacaine on stress hormone levels and the duration of caudal analgesia. Paediatr Anaesth. 15:580-5.

Akula KK, Dhir A. Kulkarni SK (2007). Proconvulsant effect of cefazolin sodium against pentylenetetrazol or Picrotoxin- induced convulsions in mice. Indian J Exp Biol. 45: 720-725.

Barbalho PG, Lopes-Cendes I, Maurer-Morelli VC (2016). BMC Neurosci 17:12DOI 10.1186/s12868-0160246-y.
Belfield A, Goldberg D M (1971). Normal ranges and diagnostic value of serum $5^{\prime}$ nucleotidase and alkaline phosphatase activities in infancy. Archives of disease in childhood 46: 842-846.

Beutler E, Duron O, Kelly BM (1963). Improved method for the determination of blood glutathione. J Lab Clin Med 61: 882-8.

Bowers LD, Wong ET (1980). Kinetic serum creatinine assays. II. A critical evaluation and review. Clinical chemistry, 26: 555-561.

Canbaz H, Akca T, Tataroglu C, Caglikulekci M, Dirlik M, Ayaz L, Ali B, Ustunsoy BT, Suha A. (2007) the Effects of Exogenous L-Carnitine on Lipid Peroxidation and Tissue Damage in an Experimental Warm Hepatic Ischemia-Reperfusion Injury Model. Current therapeutic research 68: 1 .

Constantini D, Verhulst S (2009). Does high antioxidant capacity indicate low oxidative stress? Funct Ecol 23: 506-509.

Corvino V, Marchese E, Michetti F, Geloso MC (2013). Neuroprotective strategies in hippocampal neurodegeneration induced by the neurotoxicanttrimethyltin. Neurochem Res. 38(2): 240253.

Costello DJ, Delanty N (2004). Oxidative injury inepilepsy: potential for antioxidant therapy? Expert Rev Neurother 4(3):541-553.

Dillioglugil MO, Kir HM, Demir C, Ilbay G, Sahin D, Dillioglugil O, Bambal G, Mekik H, Ates N (2010). Effect of pentylenetetrazole and sound stimulation induced single and repeated convulsive seizures on the MDA, GSH and NO levels, and SOD activities in rat liver and kidney tissues. Brain Res Bull. 83:356-359.

Fisher Robert S, Acevedo C, Arzimanoglou A, Bogacz A, Helen CJ, Elger CE, Jerome EJ, Lars F, Jacqueline AF, Mike G, Dale CH, Lee BI, Gary WM, Solomon LM, Emilio P, ingrid ES, Torbjorn T, Masako W, Samuel W (2014). A practical clinical definition of epilepsy. Epilepsia, 55(4):475-482,

Halliwell B, Gutteridge JMC (2007). Free radicals in biology and medicine. Oxford: New York Oxford University Press, Inc. p. 851.

Hermann BP, Jan Jones JE, Jackson DC, Seidenberg $M$ (2012). Starting at the beginning The neuropsychological status of children with new onset epilepsies. Epileptic Disord. 14(1): 12-21.

Koczka N, Móczár Z, BányaiÉ., Ombódi A (2015). Differences in antioxidant properties of ginkgo leaves collected from male and female trees. Acta Pharm, 65: 99104.

Koracevic D, Koracevic G, Djordjevic V, Andrejevic S and Cosic V. (2011). Method for the measurement of antioxidant activity in human fluids. J Clin Pathol. 54: 356-61.

Nasir SA, Sharma A., Khanam R, Vohora D (2012). Effect of medroxyprogesterone on development of pentylenetetrazole-induced kindling in mice. Neuroscience 5 (207): 283-287.

Naziroğlu M, Kutluhan S, Uğuz AC, Celik O, Bal R, Butterworth PJ (2009). Topiramate and vitamin e modulate the electroencephalographic records, brain microsomal and 
blood antioxidant redox system in pentylentetrazol-induced seizure of rats. J Membr Biol 229:131-140.

Naziroglu M (2007). New molecular mechanisms on the activation of TRPM 2 channels by oxidative stress and ADP-ribose. Neurochem Res 32: 1990-2001.

Nieoczym D, Albera E, Kankofer M (2008). Maximal electroshock induces changes in some markers of oxidative stress in mice. J Neural Transm. 115:19-25.

Nishikimi M, Roa N.A, Yogi K (1972). Biochem Bioph Res Common. 46: 849-854.

Noaishi A, Afify MM, Amr A (2013). Study the inhalation exposure effect of pesticides mixture in the white rat. Nature and Science 11(7):45-54.

Nuhu A (2014). Ginkgo biloba: A 'living fossil' with modern day phytomedicinal applications. Journal of Applied Pharmaceutical Science, 4 (3): 096-103.

Ochoa JG, Riche W (2012). Antiepileptic drugs. medscape.com/article/1187334-overview.

Ohkawa H, Ohishi W, Yagi K (1979). Assay for lipid peroxidation in animal tissues by thiobarbituric acid. Reaction Anal Biochem 95: 351-358

Ozsoy SY, Ozsoy B, Ozyildiz Z, Aytekin I (2011). Protective effect ofL-carnitine on experimental lead toxicity in rats: a clinical,histopathological and immunohistochemical study. Biotech Histochem 86: 436443.

Pochini L, Scalise M., Galluccio M., Indiveri C (2013). OCTN cation transporters in health and disease: role as drug targets and assay development. J Biomol Screen. 18 (8): 851-867.

Reitman S, Frankel S (1957). A colorimetric method for the determination of serum glutamic oxalacetic and glutamic pyruvic transaminases. American J clinical pathology 28: 56.
Rodriguez de Turco EB, Droy-Lefaix MT, Bazan NG (1993). Decreased electroconvulsive shockinduceddiacylglycerols and free fatty acid accumulation in the rat brain by Ginkgo biloba extract (EGb 761): selective effect in hippocampus as compared with cerebral cortex. J Neurochem. 61: 1438-1444.

Sato S, Miyake T, Tobita H, Oshima N, Ishine J, Hanaoka T, Amano Y, Kinoshita Y (2009). A dose-up of ursodeoxycholic acid decreases transaminases in hepatitis C patients. World J Gastroenterol. 15(22): 2782-2786.

Spencer RM, Karmarkar U. and Ivry RB. (2009). Evaluating dedicated and intrinsic models of temporal encoding by varying context. Philos Trans R SocLond B Biol Sci. 364:1853-1863.

Thapa BR, Walia A (2007). Liver function tests and their interpretation. Indian J Pediatr 74: 663-671.

Tousson E, Atteya Z, El-Atrash A, Jeweely OI (2014). Abrogation by Ginkgo biloba leaf extract on hepatic and renal toxicity induced by methotrexate in rats. $\mathrm{J}$ Cancer Research and Treatment, 2(3): 44-51.

Tousson E, Hafez E, Zaki S, and Gad A (2014). P53, Bcl-2 and CD68 expression in response to amethopterininduced lung injury and ameliorating role of 1-carnitine: Biomed Pharmacother, 68: 631-9.

Tousson E, Bayomy FF, El-sendiony BF (2015). Effects of L-carnitine and Ginkgo biloba on cerebral cortex in experimentally-induced epileptic seizures disease in rat. J Bioscience and Applied Res. 1(6):277-289 